Fecha de recepción: mayo 2014 Fecha de aceptación: mayo 2015 Versión final: julio 2016

\section{Vestes del tiempo: telas, movimientos e intervalos en la película Lavoura Arcaica}

Denise Trindade *

Resumen: En este artículo, proponemos pensar la importancia de las ropas como aquello que retiene el tiempo, no sólo en el aspecto efímero y transitorio de la moda, pero también en lo que en ella permanece de recuerdos y memoria, haciendo visible el propio tiempo como pasaje. En la película brasileña Lavoura Arcaica, de Luiz Fernando Carvalho, la mezcla entre presente, pasado y futuro ocurre a través de los aromas que las telas exhalan, evocando imágenes de deseo, de seducción y de muerte, revelando a través de la cámara lo que las manos del personaje sienten al tocar el sueño arrugado de los camisones y de las piyamas.

Palabras clave: imágenes - memoria - ropas - tiempo.

[Resúmenes en inglés y portugués en la página 130]

${ }^{(*)}$ Doctora en Comunicaciones y Cultura (ECO/UFRJ). Profesora de Teoría de la Imagen en el Curso de Cine de la Universidad Estácio de Sá. Investigadora en Poéticas Visuales (Faperj). Coordina el Posgrado en Artes Visuales (UNESA). Ha organizado dos libros sobre cine: Imaginería de Cine (impreso) e Imaginería de Cine y Moda (e-book).

(...) alguna vez se te ha cruzado la mente, un instante corto que fuera, suspender la tapa del cesto de la ropa sucia del baño? Alguna vez se te ocurrió hundir las manos precarias y traer con cuidado cada pieza allí tirada? Era el pedazo de cada uno que yo traía en ellas cuando hundía mis manos en el cesto , nadie ha oído mejor el grito de cada uno, te lo aseguro, las cosas exasperadas de la familia echadas en el silencio recatado de las piezas íntimas allí tiradas, pero bastaba ver, bastaba suspender la tapa y hundir las manos, bastaba hundir las manos para cosechar el sueño arrugado de los camisones y de las piyamas y descubrir en sus dobleces, allí perdido, la energía rizada y reprimida del más tierno vello del pubis (...) (Nassar, 2009, p. 42).

La película brasileña Lavoura Arcaica (2001) -Cultivo Arcaico, en una traducción libre-, dirigida por Luiz Fernando Carvalho, enfatiza el uso de las imágenes de las ropas tocadas por el personaje André y su importancia en la memoria de la familia, descrita en la novela de Raduan Nassar, aproximando moda y cine de una forma singular. La bella fotografía de 
Walter Carvalho y el figurín de Beth Filipecki hacen que el espectador sienta juntamente con los personajes el olor y la energía presentes en las telas, produciendo una imagen sensorial que, en su "invisibilidad", sobrepasa la información y la comunicación, conduciendo a un sentimiento de pasaje y de trance, involucrando la imaginación.

El cultivo evocado por el cineasta es metafóricamente el de las palabras, de las leyes y de su potencial de exclusión, así como de la lucha entre la tradición y la libertad (Carvalho, 2002). En el documental Que tus ojos sean atendidos (1995), realizado en Líbano por el propio director como investigación para la película, la tradición es visible a través de la vida en el cultivo que surge en un primer momento en la relación de los pastores, en su fusión con la propia naturaleza, como en el habla de uno de ellos: "Conozco a un pastor que cuando deja las cabras, cuando se aleja, ellas dejan de pastar, y adonde él va, ellas van detrás de él. Ellas están siempre con él" (Que teus olhos sejam atendidos, Carvalho, 1995). También el amor, tema de debate en el documental, se confunde, según el habla de algunos entrevistados, con el trigo:

Como haces de trigo, el amor os aprieta junto al corazón. Él os desgrana para exponer su desnudez. Él os penetra para libertaros de las pajas. Él os corroe hasta la extrema blancura. Él os machaca hasta que os tornéis maleables. Entonces él os lleva al fuego sagrado y os transforma en el pan místico del banquete divino! (Ibidem).

La naturaleza y su humanización se funden con la tradición y sus narrativas, constituyendo así un tipo de cultura simbólica.

Tales experiencias se configuran en la película Lavoura Arcaica evidenciando la ruptura entre esta tradición que se confunde con la naturaleza y una cultura de "inmigrantes". La película transcurre más o menos el año de 1940 y cuenta la historia de una familia de origen libanés en Brasil, que corresponde al origen del escritor de la novela, Raduan Nassar. En el tipo de organización que allí se instala es preponderante el habla del padre. Uno de los hijos, André, protagoniza la ruptura de este orden al salir de casa buscando afirmar sus diferencias con la figura paterna y con todo el orden allí presente. La película pone en escena el poder patriarcal como una manifestación de la ley simbólica y cultural y aborda también su transgresión radical, como la relación incestuosa de André con su hermana Ana. La importancia de la ropa en la construcción de los personajes se torna visible desde la primera escena en que André, con el pecho desnudo, recibe la visita de su hermano y los recuerdos afectivos atraviesan el encuentro.

Abotona la camisa, André!, dice el hermano después de un abrazo fraterno. Enseguida vemos una escena en que mezcladas al viento las piernas del niño André corren por los campos. Luego la imagen de sus pies que parecen revolverse entre las hojas en un movimiento de fusión con la tierra. Un pantalón corto de lino crudo integra su cuerpo a la naturaleza, como una trama entre tela, cuerpo y naturaleza. En voz off, el texto narra las sensaciones del sueño adolescente del niño. "Yo dormía en la postura quieta de una planta enferma curvada al peso de un botón rojo". Como "hilos de la atmósfera", vemos sábanas y pedazos de las telas bordadas y en crochet que se desplazan en medio a los árboles en movimiento. Y vuelve la escena en que André abotona la camisa de lino blanco, atendiendo al pedido 
del hermano. La relación entre pasado y presente es evocada a través de este gesto, apuntando la importancia que tiene en la ropa, al contrario de la planta, el botón, que viste un acto simbólico. El cuerpo desnudo, mezclado a la naturaleza en sus deseos, debe ser ahora cubierto por las interdicciones culturales.

El uso de la ropa como artificio permite que el cineasta configure de manera plena su aproximación con la narrativa, que privilegia el mundo interior de un personaje que tiene como interlocutores el tiempo y sus memorias, desde un punto de vista volteado para sí mismo, creando una sintaxis que expresa el devaneo emocional, creando así un flujo temporal en el cual las imágenes surgen de dentro para fuera, reencontrando, como quiere el director L. F. Carvalho, la vida.

\section{De adentro hacia afuera. Visibilidades y fabulación}

En el libro Sobre la película Lavoura Arcaica (2002), el cineasta revela su aproximación con la historia del arte al comentar sobre la concepción de la imaginería de la película. Además de aquella presente en la narrativa del libro de Nassar, él y el fotógrafo Walter Carvalho utilizaron como referencia obras de pintores españoles que representaron un período próximo a la dominación del Imperio Árabe en la Península Ibérica, donde predominaba el uso de fondos negros y la presencia de dorados que dialogaban con Rembrandt. "Las figuras extendidas de El Greco entran por Caravaggio, Tiziano, Van Gogh, Degas, Munch, Millet, Cèzanne, los Cristos de Velásquez, de iconografía rusa también, ya que la religión de aquella familia sería cristiana ortodoxa..." Carvalho, 2002, p.101). Por eso la predominancia de la presencia de lo que podemos llamar una estética barroca en la composición y en la luminosidad empleada en las escenas. La inestabilidad, el claro-oscuro, las imágenes pictóricas, la visión en masa traducen el clima trágico de la narrativa. Además de eso, los fondos negros alcanzan la memoria del espectador, actualizando el tiempo de la película, permitiendo una fabulación que se traduce a través de visualidades.

Según Deleuze (1992), la fabulación creadora no tiene nada que ver con un recuerdo ni con un fantasma. El artista vio en la vida algo intolerable, de modo que la naturaleza percibida por él accede a una visión que compone, a través de él, perceptos de esta vida.

... En efecto, el artista, entre elles el romancista, excede los estados perceptivos y los pasajes afectivos de lo vivido. Es un vidente, alguien que se torna. Como contaría él lo que le sucedió, o lo que imagina, ya que es una sombra?... Siempre se trata de liberar la vida allá donde ella es prisionera o de intentar hacerlo en un combate incierto (Deleuze, 1992, p. 222).

Queremos enfatizar cómo esta relación entre visualidad y fabulación se nos aparece aquí en el encuentro entre la fotografía y el figurín en esta película.

Es notable que hubo extensa investigación, en la que se buscó utilizar ropas y telas que eran usados por inmigrantes libaneses en la década de 30 o 40, y la dirección de Yurika Yamasaki les dio atención a los mínimos detalles, desde las ollas de la cocina hasta el muro 
de piedra que no debería tener lascas o fallas para asemejarse a los muros de la época. Pero según la figurinista Beth Filipeck, este trabajo requintado, que ha involucrado una investigación de material muy amplia, en la cual los cortes de época encontrados en las tiendas de antigüedades, el encaje de 1940, los materiales mencionados por el propio escritor, como el lino, el algodón grueso, la batista, las estampas, que de alguna manera "visten" a los personajes, representándolos en su esencia, no fue suficiente. "Era necesario encontrar las telas con cara de madre, tela con cara de padre, tela con cara de tierra”..., como el vestido blanco de lino de Ana que remite a pureza, a frescor, además del poético chalequito de la pastora (Filipecki en Nosso Diário, 2001).

Las ropas hicieron parte de los ensayos como tentativa de comprensión mayor del alma de cada uno. Como la estación era el invierno, los materiales usados fueron algodones gruesos, linos rústicos, muy poco color, mucha luz. Si por un lado el lino, proveniente de la familia de las lináceas, es, por su tradición, considerado tela noble en la historia de la moda, sirviendo en el Egipto antiguo para embalsamar a los faraones, representando así un símbolo de poder y de riqueza y usado en la película para reforzar la idea de nobleza de la familia, el algodón, que en Brasil tuvo inicio en la mitad del siglo XVIII, con la revolución industrial en Europa, caracteriza la integración nacional de la familia en este cultivo. El figurín también es montado de dentro para fuera, recomponiendo la vivencia encima del uso, como una marca. "De la delicadeza de los pañitos íntimos a la piel del campesino, del encaje que tiene el olor del cuerpo a la suciedad de la tierra que está lavada, hasta la sangre del trabajo" (Filipecki en Nosso Diário, 2001) confiriendo visibilidad a las fabulaciones. Tales imágenes mencionadas por la figurinista encuentran eco en las palabras de Stallybrass (2008), cuando él relaciona la ropa con la memoria. Él las identifica con las manchas presentes en las telas, en los olores que exhalan y en la forma que reciben a partir del uso. La ropa también huele a mortalidad, así como nosotros. "Es el olor por el cual un niño se apega a su frazada, una pieza de ropa, un osito de peluche, lo que sea" (Stallybrass, p.10). A pesar de la riqueza del material artístico y de la bibliografía, fue importante, según la figurinista, lidiar con las imágenes anteriores: de los arquetipos de la naturaleza, del padre, del hijo pródigo y, fundamentalmente, de la hermana, de la madre. O sea, de las manos de la madre. En su declaración sobre el proceso creativo de la película, Filipecki dice que son ellas que le dan visibilidad al figurín. "La madre es la que tenía la mano, la mano de la comida, la mano del hacer". Eran ellas que les daban vida a las telas. "No sería la madre que hizo aquellas ropas para la familia, a decir verdad?" (Filipecki en Nosso Diário, 2001). El hecho de tejer el encaje, de planchar el lino, de arreglar el pelo, de amasar la comida es constante en la película, exigiendo nuestra atención. 


\section{Ojo y mano. Una visión háptica}

Las manos componen varios planos de la película, sea la masturbación de André en el inicio de la película, la escena en que la madre acaricia el rostro de la hija, así como aquella en que ella alimenta al hijo o en que el padre castiga al hijo con latigazos, entre otras. Dice André en un momento de recuerdo con respecto a la madre:

-Pude verla en la mecedora... deshaciendo desde temprano el encaje tejido toda la vida en torno al amor y la unión de la familia... Y, viendo el peine de cabeza en su majestosa simplicidad en el pelo recogido, yo sentí por un momento que él valía un libro de historia.

La cámara acompaña el balanceo de la silla en un va y viene pendular deslizando y acariciando los pelos negros del personaje, bajo la mirada del niño.

En una escena en que la madre juega con el personaje André cuando niño, las manos se mezclan a las sábanas como en una danza, entre risas y gestos de complicidad, formando imágenes abstractas, sugiriendo una mirada menos óptica y más táctil, aproximándose a lo que Deleuze apunta como una mirada háptica. El concepto de háptico aparece primeramente en Alois Riegl, en el cual el historiador reúne las propiedades de una visión aproximada a un espacio háptico. Él opone la visión aproximada del arte griega a la visión distanciada del arte romana. Este tipo de visión es posteriormente abordado en la oposición entre Renacimiento y Barroco, propuesta por Wollflin (método formalista), que diferencia una visión linear (de las líneas y contornos) de la pictórica (de masas) y también por el modelo estético propuesto por Deleuze para comprensión de los espacios nómades. Según Bazin, Alois Riegl (1858) dirigió el departamento de artes textiles, consideradas como artes menores, conocidas como "Artes Decorativas" por su carácter más artesanal que artístico. Él desarrolla análisis sobre los textiles occidentales y orientales realizando un libro el 1983 llamado Problemas de Estilo (Riegl, 1858), en el cual hace un estudio profundo de la estilística de la ornamentación en distintas épocas, como góticos, bárbaros, etc. Este estudio servirá posteriormente como referencia para otro libro intitulado Las artes aplicadas en la época romana tardía según los descubrimientos en Austria-Hungría, en el cual, al pensar el arte romana, él la desvincula del arte griega, en la cual aquella aparece como degenerada, y reivindica una asociación a la intrusión de los bárbaros, provocando una metamorfosis de las expresiones artísticas.

A la sensibilidad táctil del clasicismo, el arte romana opone una concepción óptica que considera, a lo que parece, el concepto expreso por Hildebrand, que distinguía la estética de lo que es hecho para ser visto de cerca de la que es concebida para ser vista de lejos. (Bazin, 1989, p. 132). 
Para Deleuze (2007), con esta invasión bárbara las imágenes artísticas, al acercarse otra vez al tacto, adquieren una velocidad y una violencia y una vida que el ojo mal puede seguir. Al contrario de la representación clásica de origen griega, que crea un espacio óptico en una visión por partes, en la visión "háptica" no existe un alejamiento de las partes para reconocerlas; ella se afirma como única para el conjunto del cuadro. Deleuze (1997) cita a Worrigner en lo que este apunta diferencias entre las líneas abstractas, inorgánicas, y las orgánicas, que designarían la forma de representación que por su vez estaría ligada a un sujeto, como por ejemplo vemos en un rostro. Las líneas inorgánicas, al elevar a la intuición las relaciones mecánicas, configuran cabezas, cabellos, rasgos.

Esa línea frenética de variación, en cinta, en espiral, en zigzag, en S, libera una potencia de vida que el hombre corregía, que los organismos encerraban, y que el material exprime ahora como el rasgo, el flujo, el impulso que la atraviesa. Si todo es vivo, no es porque todo es orgánico y organizado, pero, al contrario, porque el organismo es un desvío de la vida (Deleuze, 1997, p. 212).

Según la declaración del fotógrafo Walter Carvalho (Nosso Diário, 2001), su objetivo en esta película era captar el tiempo. La visión háptica, por su proximidad, es capaz de tornar posible tal experiencia en lo que ella deshace la idea de un organismo y apunta para una vida germinal inorgánica. Al revelar las marcas de los personajes, como aquellas del suelo, de las paredes o de la tabla de la mesa, se observa un desgaste que configura la idea de una temporalidad, de un uso, estimulando la imaginación. También la iluminación, que parece invisible, hace aparecer imágenes vivas y pulsantes.

En la antológica escena de la fiesta en que la familia celebra el regreso del hijo pródigo, el tiempo es invocado como el que no permite el aprisionamiento de las cosas. Los personajes bailan. La cámara por detrás de los árboles acompaña el movimiento de los cuerpos, de las vestes, de un lado a otro, mezclando naturaleza y personas. El movimiento de las hojas de los árboles y los cuerpos son un bascular de luces y sombras. Cuando la cámara encuentra a Ana en su danza sensual y libertaria, ella muestra los objetos mundanos que André había guardado en sus pasajes por el mundo. una gargantilla ofrecida por una prostituta como recuerdo del encuentro, una flor roja en el pelo y medias vulgares. El movimiento circular de la cámara alterna estas imágines con las curvas de las faldas, el pelo, los pies y las caderas, encarnando el deseo.

El encuentro de la cámara con el movimiento de la falda de Ana es algo que escapa a cualquier tipo de representación, ofreciéndonos la vida a través de una imagen, como quiere el fotógrafo. Tocamos con los ojos el blanco de las faldas y el blanco de las ovejas, el verde del pasto y el rojo de la sangre que nos revelan la decadencia trágica de la tradición. El cuerpo es la fuente del movimiento. "No soy yo que intento escapar de mi cuerpo, es el cuerpo que intenta escapar él mismo..." (Deleuze, 2007, p. 16). Un cuerpo que apunta para lo que Deleuze llama zona de indiscernibilidad, donde a través de las deformaciones que ese cuerpo sufre desaparecen los contornos de las diferencias entre hombre y animal, 
presentando en su "carne" las posibilidades del devenir. Y Ana se torna carne a través de la danza y de los gestos que mueven las faldas. Es una imagen que nos envuelve como una tela, estimulando los sentidos pulsionales, ofreciéndose en un trance, escapando al cuadro y a la narrativa, realizando el encuentro de la mirada con el tiempo. Y, lo que se pretendía como un encuentro de unión entre la familia, se torna un espectáculo de muerte y tragedia, realizada por el propio tiempo, ya que, al contrario del cronológico (Cronos), es de un tiempo en que el instante da la dimensión de eternidad (Kairós) presente en la narrativa en la novela que la película quiere traducir. El tiempo de la familia que el padre quiere determinar es un tiempo de las tradiciones, que impide la novedad. El tiempo de André va al encuentro de la vida en su libertad y se presenta en la impetuosidad del deseo de André y en la voluptuosidad de Ana. El encuentro entre la fotografía y el figurín produce imágenes que evidencian este tiempo acentuando en su pasaje invisible los cambios, el movimiento, el flujo interminable del chorro de la vida.

\section{Referencias Bibliográficas}

Bazin, G. (1989). História da história da arte. San Pablo: Martins Fontes.

Carvalho, L. F. (2002). Sobre o filme Lavoura Arcaica. San Pablo: Ateliê Editorial.

Carvalho, W. en Nosso Diário. (2001). Extras del DVD de la película Lavoura Arcaica. Brasil. Europa Filmes.

Deleuze, G. (2007). Francis Bacon. Lógica da Sensação. Río de Janeiro: Jorge Zahar.

Deleuze, G. (1997) Guattari, F. Mil Platôs. Capitalismo e Esquizofrenia, vol. 5, ed. 34. San Pablo. (1992). O que é a filosofia? Ed. 34. San Pablo.

Filipecki, B. en Nosso Diário. (2001). Extras del DVD de la película Lavoura Arcaica. Brasil. Europa Filmes.

Nassar, R. (2009). Lavoura Arcaica. San Pablo: Companhia das Letras.

Stallybrass, P. (2008). O casaco de Marx: roupas, memória, dor. Belo Horizonte: Autêntica Editora.

\section{Filmografía}

Lavoura Arcaica. (2001). Película dirigida por Luiz Fernando Carvalho. Brasil.

Nosso Diário. (2001). Extras del DVD de la película Lavoura Arcaica. Brasil. Europa Filmes. Que teus olhos sejam atendidos. (1995). Documental realizado por Luiz Fernando Carvalho.

Producido por GNT/Globosat. 
Summary: In this article we propose to reflect about clothing as a time retainer, not only in the ephemeral and transitory aspect of fashion, but also in the memories and memory that remains in them, making visible the time as a passage. In the Brazilian film Lavoura Arcaica, directed by Luiz Fernando Carvalho, mixing between present, past and future occurs through the scents exuded by fabrics, evoking images of desire, seduction and death, revealing through the camera what the character's hands feel by touching the wrinkled dream of nightgowns and pajamas.

Keywords: cloths - images - memory - time.

Resumo: Neste artigo, se propõe pensar a importância das roupas como aquilo que retém o tempo, não somente no aspecto efêmero e transitório da moda, mas também no que nela permanece de lembranças e memória, fazendo visível o próprio tempo como passagem. No filme brasileiro Lavoura Arcaica, de Luíz Fernando Carvalho, a mistura entre presente, passado e futuro ocorre através dos aromas que os tecidos exalam, evocando imagens de desejo, de sedução e de morte, revelando através da câmara o que as mãos do personagem sente ao tocar o sonho enrugado das camisas de noite e das pijamas.

Palavras chave: imagens - memória - roupas - tempo. 